\title{
Morphological, molecular and ecological characterization of a native isolate of Steinernema feltiae (Rhabditida: Steinernematidae) from southern Chile
}

\author{
Patricia Flores ${ }^{1}$, Andrea Alvarado ${ }^{1}$, Gabriela Lankin ${ }^{1}$, Paola Lax ${ }^{2}$, Simona Prodan ${ }^{1}$ and Erwin Aballay ${ }^{*}$ (D)
}

\begin{abstract}
Background: Steinernema feltiae is an entomopathogenic nematode used in biological control programs with a global distribution. Populations of this species show phenotypic plasticity derived from local adaptation and vary in different traits, such as location and host penetration. The aim of this work was to describe a Chilean isolate of this nematode species, using integrative approaches.

Methods: Nematode morphological and morphometric studies were conducted along with molecular analysis of nuclear genes. The symbiotic bacterium was also identified by sequencing the $16 \mathrm{~S}$ rRNA gene. Some ecological characteristics were described, including the temperature requirements for the nematode life cycle and the effect of soil water content for optimal reproduction.

Results: Morphometric characterization revealed a large intra-specific variability. The isolate identity was also corroborated with the analysis of nuclear genes. Based on the $16 \mathrm{~S}$ gene, its symbiont bacteria, Xenorhabdus bovienii, was identified. The lowest, optimal and highest temperatures found to limit the infestation and reproduction on Galleria mellonella were 10,20 and $30^{\circ} \mathrm{C}$, respectively; the emergence from the host larvae occurred approximately 10 days after inoculation. Differences were observed in offspring, and 120 infective juveniles (IJ)/larva was the most prolific dose at $20^{\circ} \mathrm{C}$. The soil water content did not affect the number of IJ invaders, penetration efficacy and IJ emergence time or offspring per larva, but it caused a delay in achieving full mortality at the permanent wilting point with respect to saturation and field capacity.
\end{abstract}

Conclusions: For the first time, a Chilean isolate of S. feltiae is described in detail considering morphological, molecular and ecological aspects. The isolate was shown to be efficient in soil containing water, with optimal temperatures ranging from 15 to $25^{\circ} \mathrm{C}$ for host infestation and production of an abundant offspring; these characteristics would allow its potential use as control agents in a wide geographical area of the country.

Keywords: Biocontrol, Symbiotic bacteria, Juveniles, Adults, Taxonomy, Xenorhabdus, Temperature, Soil water content

*Correspondence: eaballay@uchile.cl

${ }^{1}$ Departamento de Sanidad Vegetal, Facultad de Ciencias Agronómicas, Universidad de Chile, P.O. Box 1004, Santiago, Chile

Full list of author information is available at the end of the article

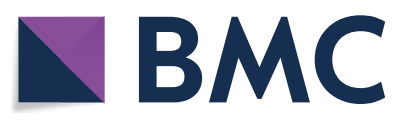

(c) The Author(s) 2021. This article is licensed under a Creative Commons Attribution 4.0 International License, which permits use, sharing, adaptation, distribution and reproduction in any medium or format, as long as you give appropriate credit to the original author(s) and the source, provide a link to the Creative Commons licence, and indicate if changes were made. The images or other third party material in this article are included in the article's Creative Commons licence, unless indicated otherwise in a credit line to the material. If material is not included in the article's Creative Commons licence and your intended use is not permitted by statutory regulation or exceeds the permitted use, you will need to obtain permission directly from the copyright holder. To view a copy of this licence, visit http://creativecommons.org/licenses/by/4.0/. The Creative Commons Public Domain Dedication waiver (http://creativecommons.org/publicdomain/zero/1.0/) applies to the data made available in this article, unless otherwise stated in a credit line to the data. 


\section{Background}

Entomopathogenic nematodes (EPNs) are lethal insect parasites that belong to the families Steinernematidae and Heterorhabditidae; its infective juveniles (IJs) carry symbiotic bacteria of the genera Xenorhabdus and Photorhabdus, respectively, within their intestines. The search for new alternatives for pest management has promoted new surveys and research in the area of biological control. The potential of EPNs for the control of insects continues to be one of the most studied alternatives, as reflected, for example, in the rate of new descriptions [1]. This surge in interest stems from the need to evaluate more intensively their potential to replace some synthetic insecticides for the control of soil-borne pests. These nematodes appear to be good insect control agents considering their easy mass production, wide host range [2] and relative safety with respect to nontarget organisms and the environment [3]. On the other hand, antimicrobial and insecticidal compounds, particularly from symbiotic bacteria, have also received special attention $[4,5]$.

A better understanding of the biology and ecology of EPN species can improve the effectiveness of biological control. It has been shown that populations of the same species from different locations may have phenotypic plasticity derived from local adaptation and may vary in different traits, such as location and host penetration capacity [6]. These behaviors are influenced by abiotic and biotic factors as well as by intrinsic nematode characteristics [7]. Knowledge of key intrinsic and extrinsic factors affecting the infection process can help optimize the management of EPNs for biological control [8].

The search for and study of EPNs in Chile is a relatively new discipline. The country has a high diversity of ecosystems, suggesting a rich fauna adapted to different environmental conditions [9]. Previous surveys detected three new species, Heterorhabditis atacamensis [10], Steinernema unicornum [11] and Steinernema australe [12], and several Steinernema feltiae isolates from different habitats [9]. The S. feltiae specimens were identified by molecular assessment of the internal transcribed spacer (ITS) rDNA region. So far, there is no complete description of any isolate of this species from Chile, including ecological aspects. For this reason, the aim of this study was to describe morphological and molecular characteristics of a new isolate, identify its symbiotic bacteria and assess some environmental requirements for the nematode life cycle under different soil and climate conditions.

\section{Methods}

\section{Nematode isolate and symbiotic bacterium culture}

The S. feltiae isolate Lican Ray (LR) was recovered from soil obtained from an oak forest near the city Lican Ray $\left(39^{\circ} 28^{\prime} 12^{\prime \prime} \mathrm{S}, 72^{\circ} 7^{\prime} 12^{\prime \prime} \mathrm{W}\right)$ by baiting the soil with greater wax moth larvae, Galleria mellonella [13]. Glass flasks of $500 \mathrm{~cm}^{3}$ were closed and kept at $20^{\circ} \mathrm{C}$ for $96 \mathrm{~h}$; the dead insects were moved to modified White traps [14], and emerging IJs were collected to infect new insect larvae to increase the population. Emergent IJs were then stored in tap water at $10^{\circ} \mathrm{C}$.

To retrieve symbiotic bacteria, a pool of IJs was surface-sterilized in $2 \% \mathrm{NaClO}$ for $3 \mathrm{~min}$, washed thoroughly with sterile water and crushed to release the bacteria. One aliquot of the homogenate was streaked onto plates with nutrient agar supplemented with $0.004 \%$ $(\mathrm{w} / \mathrm{v})$ triphenyltetrazolium chloride and $0.025 \%(\mathrm{w} / \mathrm{v})$ bromothymol blue, pH 7 (NBTA plates) $[15,16]$. On this solid culture medium, Xenorhabdus colonies exhibit a typical green-blue color, which allows them to be distinguished from potential contaminants [17]. After $48 \mathrm{~h}$ of incubation at $28^{\circ} \mathrm{C}$, colonies corresponding to the symbiotic phenotype were isolated and preserved at $-80{ }^{\circ} \mathrm{C}$ in nutrient broth supplemented with $20 \%$ glycerol.

\section{Morphological and morphometric studies}

First- and second-generation adults and IJs were collected at random from infected insect larvae [14]. Males and females were collected on the 4th and 8th days after inoculation of G. mellonella for the first and second generations, respectively, while IJs were collected within 2 days after emergence. For descriptive purposes, 25 specimens for each stage were fixed in TAF and processed to glycerin by Seinhorst's rapid method [18]. Morphological and morphometric parameters suggested by Hominick et al. [19] were analyzed using an Axiocam MRC in a Zeiss Axioimager A.1 light microscope.

For scanning electron microscopy, adults were obtained from dead G. mellonella larvae and IJs were recovered from White traps; all specimens were washed thrice in buffer M9. All nematodes were relaxed in $60{ }^{\circ} \mathrm{C}$ water, fixed in $8 \%$ glutaraldehyde and mounted according to the methodology of Koppenhöfer and Stock [20]. Scanning was performed using a Philips XL microscope with an SES DS-130 at $20 \mathrm{kV}$ accelerating voltage.

\section{Molecular characterization Nematode isolate}

DNA was obtained from single females using the extraction method of Williams et al. [21]. Nematodes were collected in PCR tubes with WLB buffer containing $10 \mathrm{mg} /$ $\mathrm{ml}$ proteinase $\mathrm{K}$ and frozen for at least $10 \mathrm{~min}$ at $-80^{\circ} \mathrm{C}$. The tubes were quickly placed in a water bath at $65^{\circ} \mathrm{C}$ and then incubated at the same temperature for $90 \mathrm{~min}$ to allow digestion by proteinase $\mathrm{K}$. Finally, proteinase $\mathrm{K}$ was inactivated by heating to $95^{\circ} \mathrm{C}$ for $15 \mathrm{~min}$, and the tubes were centrifuged to separate the supernatant. 
PCR was performed to amplify the large ribosomal subunit (LSU) 28S rDNA using forward primer no. 391 (5'-AGCGGAGGAAAAGAAACTAA-3') [22] and D3B (5'-TCGGAAGGAACCAGCTACTA-3') reverse primer [23]. One fragment of rDNA that includes the internal transcribed spacer ITS-1, the $5.8 \mathrm{~S}$ subunit and ITS-2 was PCR amplified using the primer pair 93 (5'-TTGAAC CGGGTAAAAGTCG-3') and 94 (5'-TTAGTTTCTTTT CCTCCGCT-3') [24]. In both PCRs, a volume of $2 \mu \mathrm{l}$ DNA was used as template in a $50 \mu$ reaction mix that contained $0.5 \mu \mathrm{M}$ of each primer, $200 \mu \mathrm{M}$ dNTP and 1 unit of Taq DNA Polymerase Recombinant (Invitrogen) along with $1.5 \mathrm{mM} \mathrm{MgCl}_{2}$ final concentration. Amplifications were performed in a BIOER-LifePro Thermal Cycler. To amplify the LSU fragment, the PCR mix was denatured at $94{ }^{\circ} \mathrm{C}$ for $3 \mathrm{~min}$, followed by 33 cycles of $94{ }^{\circ} \mathrm{C}$ for $30 \mathrm{~s}, 52{ }^{\circ} \mathrm{C}$ for $30 \mathrm{~s}$ and $72{ }^{\circ} \mathrm{C}$ for $1 \mathrm{~min}$, and a final extension of $7 \mathrm{~min}$ at $72{ }^{\circ} \mathrm{C}$. A similar PCR program was used for the ITS region, adjusting the annealing temperature to $60{ }^{\circ} \mathrm{C}$. The amplified fragments were separated by electrophoresis on $1 \%$ agarose $(\mathrm{w} / \mathrm{v})$ gels using $1 \mathrm{X}$ TBE buffer at $100 \mathrm{~V}$ for $1 \mathrm{~h}$ and then purified using an E.Z.N.A. Gel Extraction Kit (OMEGA Bio-tek). PCR products were sequenced (Macrogen, USA) using internal primers. Forward 502 (5'-CAAGTACCGTGAGGG AAAGTTGC-3') and reverse 503 (5'-CCTTGGTCC GTGTTTCAAGACG-3') primers were used for 28S; forward 533 (5'-CAAGTCTTATCGGTGGATCAC-3') and reverse 534 (5'-GCAATTCACGCCAAATAACGG-3') were used for ITS fragment [25].

\section{Symbiotic bacteria}

DNA was extracted from $1.5 \mathrm{ml}$ of overnight Miller's LB Broth (10 g/l Tryptone, $10 \mathrm{~g} / \mathrm{l} \mathrm{NaCl}, 5 \mathrm{~g} / \mathrm{l}$ yeast extract) culture, using a GenElute Bacterial Genomic DNA kit (Sigma, Sigma-Aldrich). Universal primers that amplify nearly the full-length $16 \mathrm{~S}$ rRNA from many bacterial genera were used: 27f ( $5^{\prime}$-AGAGTTTGATCATGGCTC AG-3') and 1492r (5'-TACGGTTACCTTGTTACG ACTT-3') [26]. The reaction was carried out in a final volume of $30 \mu \mathrm{l}$ containing $1 \mu \mathrm{l} \mathrm{DNA}, 1 \mu \mathrm{M}$ of each primer, $200 \mu \mathrm{M}$ dNTP and 1 unit Taq DNA Polymerase Recombinant (Invitrogen). PCR parameters consisted of an initial denaturation at $94{ }^{\circ} \mathrm{C}$ for $3 \mathrm{~min}, 35$ cycles of $94{ }^{\circ} \mathrm{C}$ for $50 \mathrm{~s}$, annealing at $58{ }^{\circ} \mathrm{C}$ for $50 \mathrm{~s}$ and $72{ }^{\circ} \mathrm{C}$ extension for $50 \mathrm{~s}$ followed by a final extension at $72{ }^{\circ} \mathrm{C}$ for $7 \mathrm{~min}$. PCR products were visualized, purified and sequenced as previously mentioned.

\section{Phylogenetic analysis}

The DNA sequences of the isolate LR were compared with those present in GenBank using the basic local alignment search tool (BLAST) of the National Center for Biotechnology Information (NCBI). The $28 \mathrm{~S}$ and ITS sequences and corresponding reference nucleotide sequences of Steinernema spp., including the feltiae group, available in GenBank were aligned with the default parameters of Clustal W [27]. The alignments were manually edited using BioEdit [28]. The $16 \mathrm{~S}$ sequence of the symbiotic bacteria was aligned to corresponding sequences of Xenorhabdus spp.

Phylogenetic analyses were performed with maximum likelihood (ML) based on the Tamura-Nei model [29] using the program Molecular Evolutionary Genetics Analysis Version 6.0 (MEGA 6) [30]. The estimation of the support for each node was assessed by bootstrap analysis with 1000 replicates. The dataset was also analyzed using Bayesian inference with MrBayes 3.1.2 [31]. The best fitted model of DNA evolution was obtained using jModelTest 0.1.1 [32] with the Akaike information criterion. The GTR + G model (ITS and 28S) and GTR+G+I models (16S) were selected. Two independent runs were performed simultaneously on the data, each one using one cold and three heated chains. After 5 million generations, the average standard deviations of split frequencies between the two independent runs at completion were 0.005 (ITS and 16S) and 0.006 (28S). After discarding $25 \%$ of burn-in samples and evaluating convergence, the remaining samples were retained for further analyses. The topologies were used to generate a 50\% majority rule consensus tree. Posterior probabilities are given on appropriate nodes. Trees were visualized using TreeView [33]. The newly obtained sequences were submitted to the NCBI GenBank database under the accession numbers indicated in bold on the phylogenetic trees.

\section{Ecological characteristics}

Different experiments were performed to determine the optimal conditions of the nematode life cycle.

\section{Effect of temperature}

The optimal temperature for insect mortality, IJ penetration rate, days to emerge from the insect cadaver and offspring production were determined. One hundred IJs were applied in $0.2 \mathrm{ml}$ of water per G. mellonella larva in petri dishes (3.5 cm diameter) with a filter paper on the bottom. Plates were covered with a plastic bag to maintain humidity and stored in an incubator at different temperatures $\left(5,10,15,20,25\right.$ and $\left.30^{\circ} \mathrm{C}\right)$. Each treatment had five replicates distributed in a random design; each replicate consisted of a group of four plates and four larvae per plate. Insects were checked during 5 days to determine mortality; the larva was considered dead when it did not respond to being touched with a needle. One day after death, the cadaver was dissected, and the number of IJs inside the body was counted to estimate the 
penetration rate. Offspring were determined by counting the total number of emerged IJs from dead larvae in a modified White trap. Nematodes were recovered and stored at $10{ }^{\circ} \mathrm{C}$ in Falcon tubes every day, until no new IJs were detected.

\section{Lethal concentration}

A similar assay allowed evaluating the same parameters and the IJ penetration efficacy at different inoculum densities. Each petri dish, containing one G. mellonella larva, was inoculated by applying different doses per larva $(0$, $10,20,40,80$ and $240 \mathrm{IJs} / 0.2 \mathrm{ml}$ water). During 4 days, plates were incubated at $20^{\circ} \mathrm{C}$, with the optimal temperature determined on the previous assay. Penetration efficacy (\%) was calculated according to the formula of Kaya and Stock [14], which relates the number of nematodes recovered from dissection with those inoculated. Recovered nematodes were maintained as indicated above. Mortality percentages at $48 \mathrm{~h}$ were used to estimate the lethal concentration (LC).

Effect of soil water content: Substrates containing three water levels, permanent wilting point, field capacity and saturation, were used to determine IJs infestation capacity. The substrate consisted of a steamed mixture of uniform proportions of sand, agricultural soil and organic matter, with a content of clay, silt and sand of 13.2, 22.9 and $63.9 \%$, respectively. The texture was sandy loam. Petri dishes $(3.5 \mathrm{~cm}$ diameter, with a filter paper on the bottom) containing $4.5 \mathrm{~g}$ of the substrate were inoculated with $120 \mathrm{IJs} / 0.2 \mathrm{ml}$ water. This nematode density was selected according to assay 2.4.2; after $30 \mathrm{~min}$, one G. mellonella larva was placed in each petri dish, stored under the conditions previously indicated and incubated at $20{ }^{\circ} \mathrm{C}$. The experimental design and the variables evaluated were the same as those mentioned above.

\section{Data analysis}

The three experiments were repeated twice under the same conditions. For all the assays, mortality was corrected according to Abbot's formula [34]. The percentage data were arcsine transformed (angular transformation), and normality and variance homogeneity were verified prior to performing an ANOVA using the program Minitab V 15. The other variables were analyzed with no transformations. A Tukey test was performed in case the ANOVA showed significant differences $(P<0.05)$. To determine $\mathrm{LC}_{50}$ and $\mathrm{LC}_{90}$, mortality at $48 \mathrm{~h}$ was considered; data were analyzed using the Probit Program V 1.5.

\section{Results}

Morphological and morphometric studies (Table 1, Figs. 1, 2, 3)

\section{Male, first generation}

Body C- or J-shaped posteriorly when heat-killed (Fig. 1a). Cuticle with fine, annular striation under SEM but smooth under light microscope; lateral fields and phasmids inconspicuous. Anterior end slightly rounded, continuous with the body. Six prominent lips, each lip bearing a labial papilla. Four cephalic papillae, also notorious (Fig. 3b, d). Small amphidial opening, behind to lateral lip papillae. Deirids conspicuous, located in the first third, after than excretory pore. Stoma short and wide, inconspicuous sclerotized walls. Esophagous muscular with cylindrical procorpus, metacorpus slightly swollen, isthmus fairly notorious, ending in a pyriform basal bulb. Nerve ring surrounding the isthmus or the anterior end of basal bulb. Excretory pore anterior to the nerve ring, around first third of the isthmus (Fig. 1c). Simple testis, reflexed. Vas deferens with inconspicuous walls. Spicules paired, symmetrical, curved, ocher brown color (Fig. 1g); head (manubrium) oblong, shaft (calomus) notorious, velum present. Gubernaculum curved, approximately 2/3 of spicule's length; boat-shaped in lateral view, anterior end curved ventrally (Fig. 1g); in ventral view, corpus with two projections. Tail conoid, tail terminus with a mucron (Fig. 1e). One single, midventral, precloacal papilla, and 11 pairs of papillae. Six pairs are precloacal, subventral, one pair lateral precloacal, one pair adanal, two pairs subterminal subventral and one pair post cloacal, lateral (Fig. 1f).

\section{Male, second generation}

Similar to the first-generation male, but more slender and smaller in body length and other morphometric characters. Deirids not observed. Mucron on tail terminus present and longer than that in the first generation.

\section{Females, first generation}

Body robust, habitus C-shaped (Fig. 2a). Cuticle, lips, stoma and esophageal region as in males. Excretory pore at mid of metacorpus (Fig. 2b). Reproductive system didelphic-amphidelphic, ovary reflexed dorsally. Vulva a transverse slit at midbody region, protuberant, with a double epiptygma (Fig. 2d). Vagina short, leading into paired uteri. Tail conoid with ventral postanal swelling (Fig. 2e). Mucron absent. 
Table 1 Morphometrics of Steinernema feltiae isolate Lican Ray, Chile

\begin{tabular}{|c|c|c|c|c|c|}
\hline \multirow[t]{2}{*}{ Character } & \multicolumn{2}{|l|}{ Male generation } & \multicolumn{2}{|l|}{ Female generation } & \multirow[t]{2}{*}{ Third juvenile stage } \\
\hline & $1^{\circ}$ & $2^{\circ}$ & $1^{\circ}$ & $2^{\circ}$ & \\
\hline$n$ & 25 & 25 & 25 & 25 & 25 \\
\hline L & $1428 \pm 86(1309-1578)$ & $866 \pm 75(731-1004)$ & $5318 \pm 907(3856-7327)$ & $3269 \pm 286(2890-3930)$ & $807 \pm 21(779-841)$ \\
\hline MBW & $95 \pm 7(85-116)$ & $53 \pm 5(44-64)$ & $189 \pm 27(156-243)$ & $154 \pm 11(131-173)$ & $31 \pm 4(27-41)$ \\
\hline ES & $143 \pm 10(122-177)$ & $115 \pm 9(99-138)$ & $167 \pm 17(141-200)$ & $166 \pm 15(136-200)$ & $119 \pm 7(104-130)$ \\
\hline EP & $101 \pm 9(80-118)$ & $72 \pm 7(61-86)$ & $90 \pm 17(46-118)$ & $85 \pm 14(67-117)$ & $55 \pm 3(50-60)$ \\
\hline NR & $113 \pm 11(90-144)$ & $85 \pm 7(71-101)$ & $117 \pm 16(93-149)$ & $114 \pm 13(86-140)$ & $87 \pm 5(80-98)$ \\
\hline $\mathrm{TL}$ & $39 \pm 3(35-47)$ & $35 \pm 3(31-40)$ & $55 \pm 6(42-64)$ & $48 \pm 7(37-62)$ & $74 \pm 3(68-78)$ \\
\hline ML & $5 \pm 1(4-8)$ & $11 \pm 2(8-14)$ & & & \\
\hline$A B D$ & $40 \pm 4(35-48)$ & $32 \pm 3(25-39)$ & $65 \pm 15(42-91)$ & $47 \pm 6(37-60)$ & $16 \pm 1(14-20)$ \\
\hline SpL & $68 \pm 5(58-78)$ & $57 \pm 6(42-65)$ & & & \\
\hline GuL & $46 \pm 3(40-55)$ & $36 \pm 4(29-45)$ & & & \\
\hline SW & $1.7 \pm 0.2(1.3-2.1)$ & $1.8 \pm 0.3(1.3-2.4)$ & & & \\
\hline GS & $0.7 \pm 0.05(0.6-0.8)$ & $0.6 \pm 0.1(0.5-0.7)$ & & & \\
\hline V & & & $50 \pm 2(46-55)$ & $53 \pm 3(49-58)$ & \\
\hline a & & & & & $26 \pm 3(19-31)$ \\
\hline$b$ & & & & & $7 \pm 0.4$ \\
\hline c & & & & & $11 \pm 0.4(10-12)$ \\
\hline $\mathrm{D} \%$ & $71 \pm 7(56-84)$ & $62 \pm 6(52-79)$ & $54 \pm 10(33-67)$ & $51 \pm 7(39-62)$ & $46 \pm 4(40-55)$ \\
\hline $\mathrm{E} \%$ & $261 \pm 32(202-326)$ & $207 \pm 27(162-252)$ & $165 \pm 36(76-232)$ & $180 \pm 44(118-263)$ & $75 \pm 5(67-83)$ \\
\hline $\mathrm{H}$ & & & & & $26 \pm 4(17-33)$ \\
\hline $\mathrm{H} \%$ & & & & & $36 \pm 6(23-45)$ \\
\hline
\end{tabular}

Measurements are in $\mu \mathrm{m}$, except the indexes, in form: mean \pm standard deviation (range)

L: total body length; MBW: maximum body width; ES: esophagus length; EP: anterior end to excretory pore; NR: anterior end to nerve ring; TL: tail length; ML: mucron length; $A B D$ : anal body diameter; $\mathrm{SpL}$ : spicule length; GuL: gubernaculum length; $\mathrm{H}$ : hyaline portion; $\mathrm{V}$ : position of vulva $(\%) ; \mathrm{D} \%$ : $(\mathrm{EP} / \mathrm{ES}) \times 100 ; \mathrm{E} \%=(\mathrm{EP} / \mathrm{TL}) \times 100$; $\mathrm{SW}=\mathrm{SpL} / \mathrm{ABD} ; \mathrm{GS}=\mathrm{GuL} / \mathrm{SpL} ; \mathrm{H} \%=(\mathrm{H} / \mathrm{TL}) \times 100 ; \mathrm{a}=\mathrm{L} / \mathrm{MBW} ; \mathrm{b}=\mathrm{L} / \mathrm{ES} ; \mathrm{c}=\mathrm{L} / \mathrm{TL}$

\section{Females, second generation}

Similar to first-generation females (Fig. 2c), but smaller in size. Vulva located slightly back compared to the firstgeneration females, symmetric and protuberant lips with a double epiptygma. Relation excretory pore/tail length bigger than in the first generation. Tail conoid, with a slight postanal swelling (Fig. 2f).

\section{Third juvenile stage}

Body slender, habitus straight. Cuticle with fine transverse striae. Head continuous with body contour, slightly truncate (Fig. 3a), not annulated. Labial papillae not observed, amphidial opening like a pore at the level of four distinct cephalic papillae (Fig. 3b). Oral aperture and anus closed. Lateral fields with eight notorious ridges at midbody region (Fig. 3c). Long esophagous, narrow, procorpus slightly expanded, narrowing in isthmus and base bulb pyriform (Fig. 3a). Excretory pore at mid-esophagous level, isthmus surrounded by nerve ring. Deirids not observed. Cardia present. Small bacterium receptacle in the anterior part of intestine. Tail conoid, tapering gradually (Fig. 3d, e), hyaline portion equivalent to $36 \%$ of tail length (Fig. 3d).

\section{Molecular characterization}

For the ITS region a fragment of 859 bp was obtained for the Chilean S. feltiae isolate. This sequence was tested in BLAST with data deposited in GenBank, showing approximately 97-99\% similarity with sequences of the same species. The majority-rule consensus tree of the Bayesian inference showed a well-supported group (100\% bootstrap) that comprised the LR isolate (MK504438) and known sequences of S. feltiae from different countries, including one from Chillán, Chile (MK504439), sequenced in the present work as reference (Fig. 4). For 28S, a fragment of 894 bp was obtained (MK509752) showing 99\% similarity with published sequences of $S$. feltiae and other species from the feltiae group. The phylogenetic relationships revealed a clade (100\% bootstrap) that included sequences of S. feltiae from different geographical origins including Chillán, Chile (MK509780), and from Steinernema jollieti, Steinernema puntauvense, Steinernema litorale, Steinernema ichnusae, Steinernema weiseri and Steinernema silvaticum (Fig. 5). Based on the BLAST search and phylogenetic analysis of $16 \mathrm{~S}$ rRNA, the symbiotic bacterium of S. feltiae LR is Xenorhabdus bovienii (BLAST similarities 

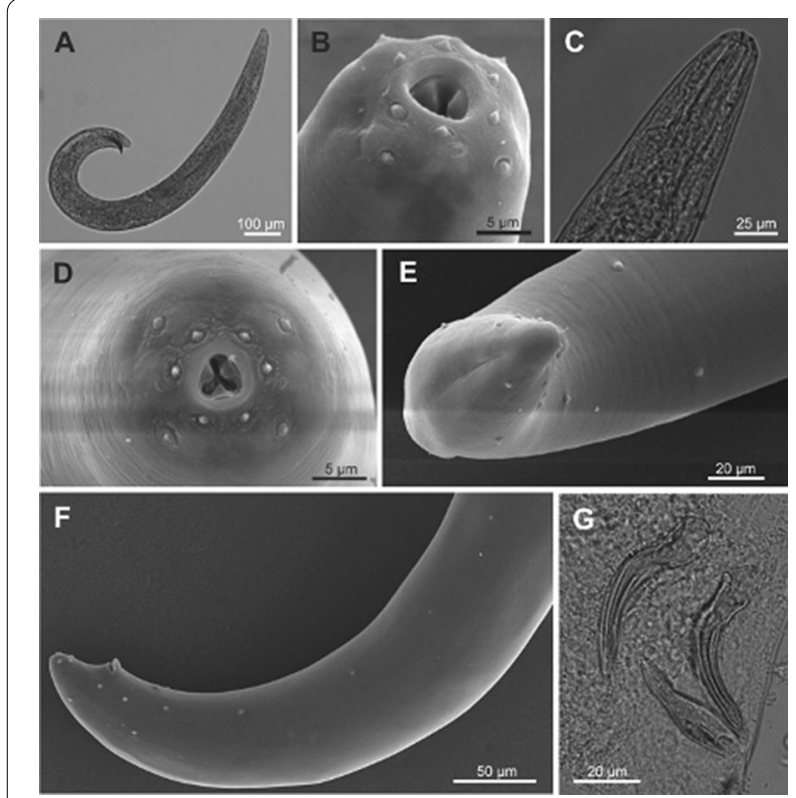

Fig. 1 Steinernema feltiae isolate from Lican Ray, Chile. Male, first generation. a Entire body; $\mathbf{b}$, $\mathbf{d}$ cephalic region, showing lips, labial papillae and cephalic papillae and amphids; c anterior region, showing excretory pore location; e tail with mucron; $\mathbf{f}$ posterior region, showing genital papillae; $\mathbf{f}$ spicules and gubernaculum

99\%). The Bayesian inference showed that the sequence obtained (MK504451) formed a well-supported group with sequences of the same species deposited in GenBank (Fig. 6). ML analysis produced trees with the same topology for all the genes considered.

\section{Ecological characteristics}

\section{Observations of the cycle of $L R$ isolate}

The life cycle of the LR isolate was similar to those described for other Steinernema species. The IJs were able to kill G. mellonella larvae between the 1st and 2nd day after inoculation at $20{ }^{\circ} \mathrm{C}$. Males and females of the first generation were present on the 3rd or 4th day. On the 5th day, the first IJs were observed in the insect cadaver. A second adult generation occurred between the 7th and 8th days. IJs emerged massively from the insect body on the 10th day. The color of insect larvae turned brown when they died.

\section{Effect of temperature}

The effect of IJs on G. mellonella mortality at different temperatures is shown in Table 2. On the 2nd day, most larvae incubated at $20{ }^{\circ} \mathrm{C}$ or higher were immobile and starting to change color. While at $5^{\circ} \mathrm{C}$, no mortality was recorded, at $10{ }^{\circ} \mathrm{C}$, a few dead larvae $(10 \%)$ were observed on day 5 after inoculation (DAI). Mortality increased dramatically with higher temperatures, reaching $100 \%$ at 15 ,

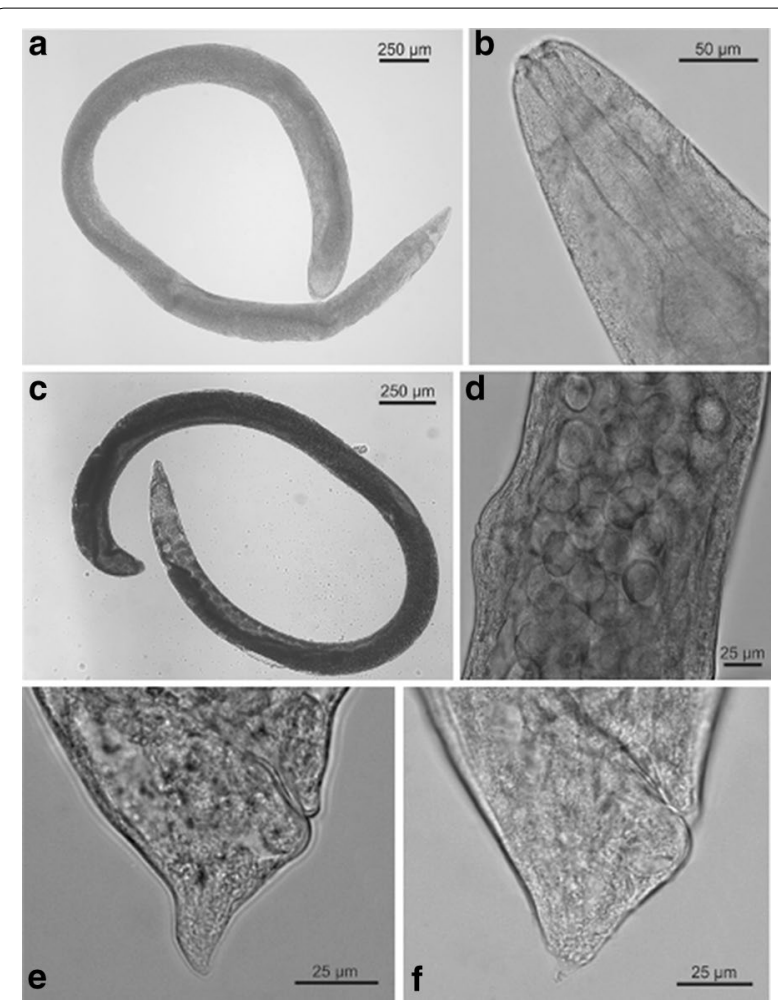

Fig. 2 Steinernema feltiae isolate from Lican Ray, Chile. Female. First generation. a Entire body; $\mathbf{b}$ anterior region, showing esophagus and excretory pore. Second generation. $\mathbf{c}$ Entire body. First generation. $\mathbf{d}$ Vulvar region; e tail. Second generation. f Tail

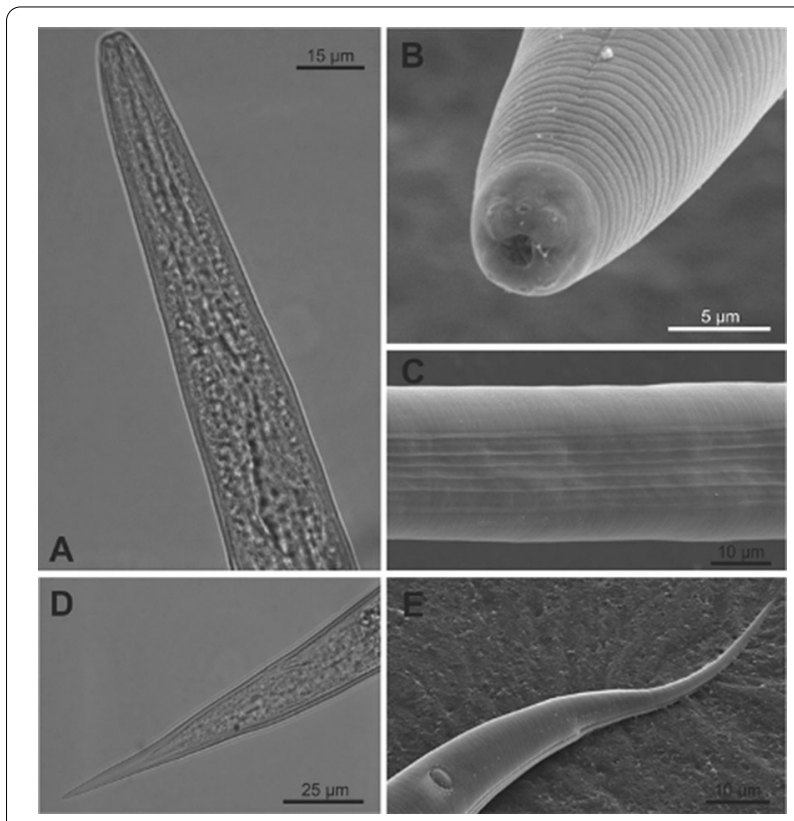

Fig. 3 Steinernema feltiae isolate from Lican Ray, Chile. Third juvenile stage. a Anterior region, showing esophagus; $\mathbf{b}$ anterior region, showing cephalic papilla and amphid; c lateral field at midbody; $\mathbf{d}$ hyaline portion; e Tail 
20 and $25{ }^{\circ} \mathrm{C}$ on the 3rd DAI. The last two temperatures seemed to be optimal for reaching the highest mortality in the shortest period, with a $90-97.5 \%$ mortality on the 2nd DAI. The highest temperature $\left(30^{\circ} \mathrm{C}\right)$ had an effect on mortality, reaching the maximum value on the 5th DAI.

The number of invader IJs per G. mellonella larva at different temperatures is presented in Table 3. At the lowest

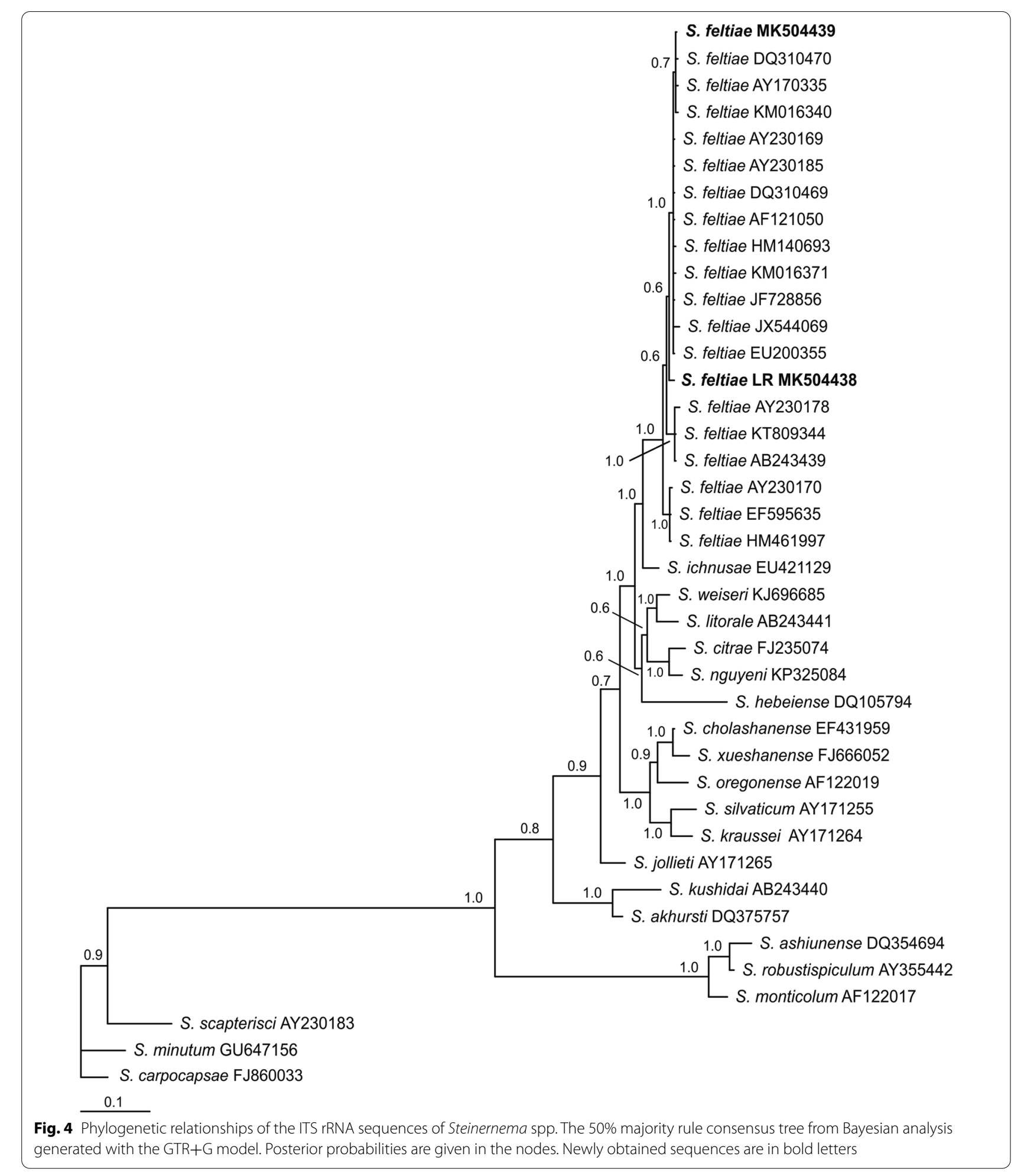


evaluated temperatures $\left(5\right.$ and $\left.10{ }^{\circ} \mathrm{C}\right)$, nematode presence was not detected by dissection. IJ penetration was higher at 15 and $20{ }^{\circ} \mathrm{C}$ (approximately $25 \%$ of IJs inoculated) and significantly decreased as temperature increased.
Females with eggs were observed on the 2nd day after larval death at 15,20 and $25^{\circ} \mathrm{C}$. The time for emergence of IJs (Table 3) from the insect cadaver was optimal for medium temperatures $\left(15\right.$ and $\left.20^{\circ} \mathrm{C}\right)$, coming out of the

S. litorale JQ795723

S. weiseri DQ400854

S. ichnusae EU421130

S. silvaticum DQ399663

S. jollieti GU569051

S. feltiae HM140683

0.8

S. feltiae JF920966

S. feltiae JF920963

S. feltiae JX436334

1.0

S. weiseri GU569059

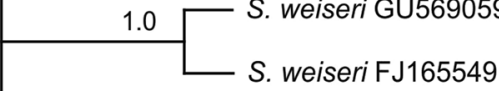

0.7

0.8

S. feltiae HM140687

S. feltiae JN886644

S. feltiae JN886669

S. feltiae LR MK509752

S. puntauvense EF187018

S. feltiae AY169562

S. feltiae EU598250

0.8

S. feltiae JF728852

S. feltiae AF331906

S. feltiae GU569050

S. feltiae GU569049

S. feltiae MK509780

0.9

S. texanum EF152569

S. xueshanense FJ666053

S. oregonense AF331891

S. akhursti KF289902

S. kushidai AF331897

0.01

Fig. 5 Phylogenetic relationships of the $28 \mathrm{~S}$ rRNA sequences of Steinernema spp. The $50 \%$ majority rule consensus tree from Bayesian analysis generated with the GTR+G model. Posterior probabilities are given in the nodes. Newly obtained sequences are in bold letters 
insect around the 10th DAI. At the lowest $\left(5\right.$ and $10{ }^{\circ} \mathrm{C}$ ) and highest $\left(30{ }^{\circ} \mathrm{C}\right)$ temperatures, neither IJ emergence nor offspring were observed. The greatest IJ production occurred at $20{ }^{\circ} \mathrm{C}$. The maximum IJs recovery occurred during the 5th DAI, and the emergence lasted for 30 days (data not shown). The optimal temperature for host invasion and reproduction of $S$. feltiae LR was $20^{\circ} \mathrm{C}$, so this temperature was used for the following assays.

\section{Lethal concentration}

Insect mortality percentages obtained during 4 DAIs are presented in Table 4, showing that mortality increased as the inoculum and DAI increased. On the 3rd day, 100\% mortality was reached for all nematode doses; however, on the 2nd day, over 80 IJs were enough to achieve maximum control. The $\mathrm{CL}_{50}$ and $\mathrm{CL}_{90}$ at $48 \mathrm{~h}$ were 7.2 and 40.4 IJs/larva, respectively.

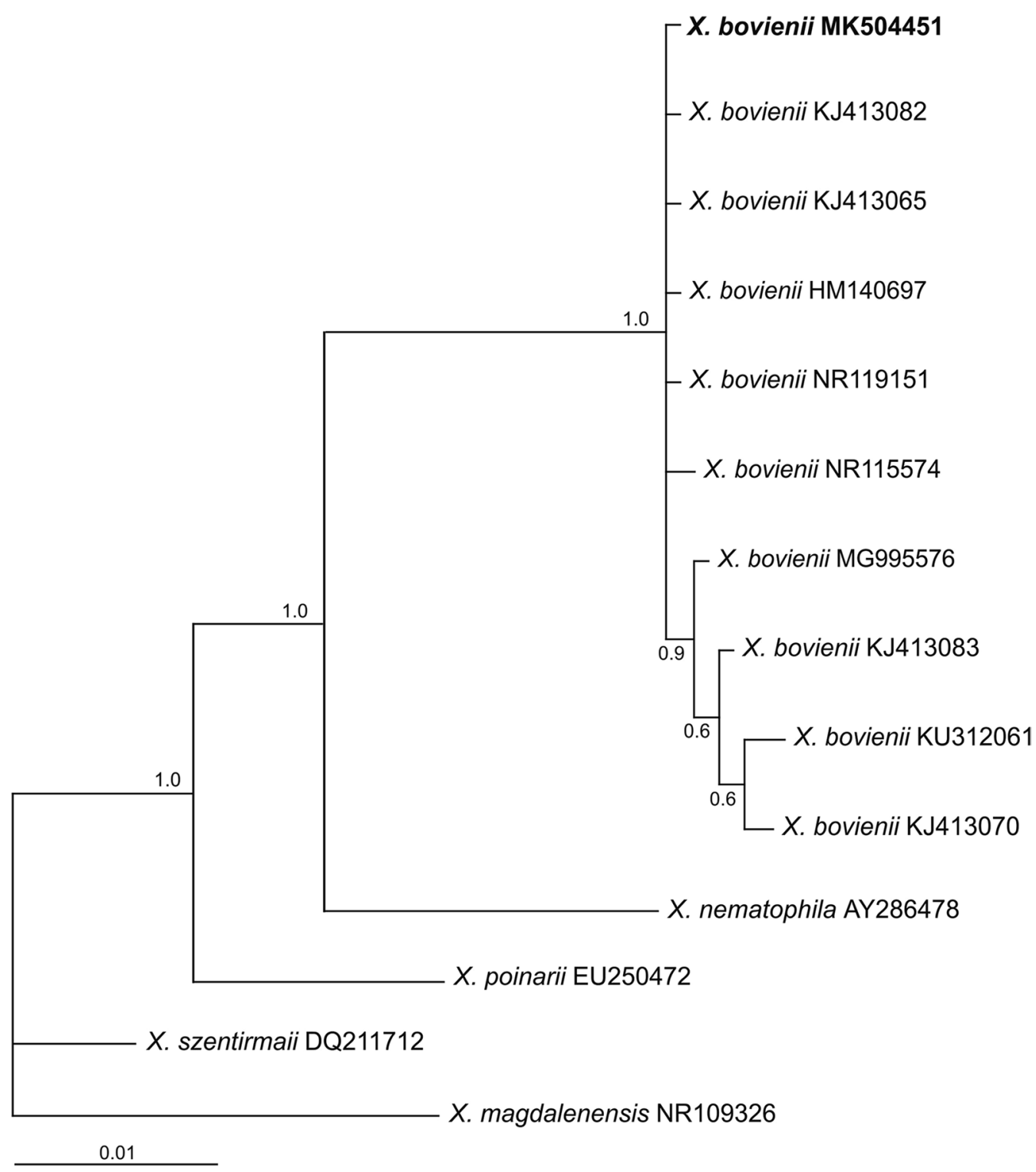

Fig. 6 Phylogenetic relationships of the 16S rRNA sequences of Xenorhabdus spp. The 50\% majority rule consensus tree from Bayesian analysis generated with the GTR+G+I model. Posterior probabilities are given in the nodes. Newly obtained sequences are in bold letters 
Table 2 Percent mortality of Galleria mellonella larvae at different temperatures during the 5 days after inoculation with infective juveniles of Steinernema feltiae LR

\begin{tabular}{llllll}
\hline Temperature $\left({ }^{\circ} \mathrm{C}\right)$ & \multicolumn{5}{l}{ Days after inoculation } \\
\cline { 2 - 6 } & 1 & 2 & 3 & 4 & 5 \\
\hline 5 & $0 a^{\mathrm{x}}$ & $0 \mathrm{a}$ & $0 \mathrm{a}$ & $0 \mathrm{a}$ & $0 \mathrm{a}$ \\
10 & $0 \mathrm{a}$ & $0 \mathrm{a}$ & $0 \mathrm{a}$ & $0 \mathrm{a}$ & $10 \mathrm{a}$ \\
15 & $0 \mathrm{a}$ & $0 \mathrm{a}$ & $100 \mathrm{c}$ & $100 \mathrm{~b}$ & $100 \mathrm{~b}$ \\
20 & $0 \mathrm{a}$ & $97.5 \mathrm{c}$ & $100 \mathrm{c}$ & $100 \mathrm{~b}$ & $100 \mathrm{~b}$ \\
25 & $0 \mathrm{a}$ & $90 \mathrm{c}$ & $100 \mathrm{c}$ & $100 \mathrm{~b}$ & $100 \mathrm{~b}$ \\
30 & $12.5 \mathrm{~b}$ & $60 \mathrm{~b}$ & $90 \mathrm{~b}$ & $95 \mathrm{~b}$ & $100 \mathrm{~b}$
\end{tabular}

${ }^{x}:$ Means $(n=20)$ in columns followed by the same letter do not differ significantly according to Tukey's multiple range test $(P<0.05)$

The number of nematodes invading the host increased with dose (Table 5); however, efficacy of penetration, ranging from 24 to $49.6 \%$, did not show statistical differences. Independent of IJ inoculum dose, no significant differences were observed respect to the time needed for new IJs to start to emerge from the insect cadaver, varying between 11 and 13.5 days. Differences were observed in the offspring emerging from the host, where doses of $120 \mathrm{IJs} /$ larva were the most prolific. This nematode dose was used to investigate effects of soil water content.

\section{Effect of soil water content}

The effect of soil water content on the mortality of $G$. mellonella over 5 days is shown in Table 6 . On the 2nd and 3rd days, differences were observed between water contents; however, on the 4th day, mortality was statistically similar for all treatments, showing a delay in achieving full mortality. Water content did not affect the number of IJ invaders or penetration efficacy (Table 7).

Table 3 Number of invader infective juveniles (IJs) per Galleria mellonella larva, time to emerge from the cadaver and offspring production (IJs/larva) after inoculation at different temperatures

\begin{tabular}{llll}
\hline $\begin{array}{l}\text { Temperature } \\
\left({ }^{\circ} \mathrm{C}\right)\end{array}$ & Invader IJs & Emergence days & Offspring \\
\hline 5 & nd & nd & nd \\
10 & nd & nd & nd \\
15 & $26.6 \pm 11.4 c^{\times}$ & $17.3 \pm 1.4 \mathrm{C}$ & $72,884.9 \pm 26,417 \mathrm{~b}$ \\
20 & $26.4 \pm 11.2 \mathrm{C}$ & $10.6 \pm 1.4 \mathrm{~b}$ & $102,807.3 \pm 23,256 \mathrm{C}$ \\
25 & $12.4 \pm 7.2 \mathrm{~b}$ & $9.1 \pm 0.7 \mathrm{a}$ & $52,107.8 \pm 15,452 \mathrm{a}$ \\
30 & $3.1 \pm 2.6 \mathrm{a}$ & nd & nd \\
\hline
\end{tabular}

nd: nematodes no detected

$x$ : Means $(n=20)$ in columns followed by the same letter do not significantly differ according to Tukey's multiple range test $(P<0.05)$
The time of emergence of the IJs and offspring per larva showed no differences between treatments.

\section{Discussion}

Morphometric characteristics of S. feltiae showed a great intraspecific variability in mean values and ranges between isolates from different geographical origins [3541]. In Chile, Edgington et al. [9] collected several isolates of this species from different zones ( 3,4 and 6$)$, and, based on ITS region, they were separated into two subgroups (I and II). Morphometric characters of IJs from isolate D030 (subgroup I) were smaller than from isolate D087 (subgroup II); the isolate LR, collected from zone 4, showed intermediate sizes for IJs.

Considering the high morphometric variability of $S$. feltiae, molecular data are very useful [36]; however, a marker such as the ITS region, which has proven useful in resolving phylogenetic relationships in EPNs, has exhibited intra-specific and intra-individual variability for this species as well as others in the feltiae and glaseri group [42]. According to these authors, considering the frequency of intra-individual variability, sequencing of the D2-D3 region of $28 \mathrm{~S}$ appears to be necessary to confirm species status. However, this region is also conserved among some species of the feltiae group, as was observed when analyzing the phylogenetic relationships in the present work; other species, such as Steinernema weiseri and Steinernema puntauvense, were grouped within the $S$. feltiae clade with $99 \%$ genetic similarity. On the other hand, analysis of the 16S rRNA gene allowed for the identification of $X$. bovienii, the symbiotic bacterium of $S$. feltiae [6]. This bacterium species, like other members of the genus, produces a toxin complex with a potential use in crop protection against different insect pests $[4,43]$.

Steinernema feltiae is a common species reported in many places in the world; this species is known to

Table 4 Percentage of mortality of Galleria mellonella larvae during the 4 days after inoculation with different infective juvenile (IJs) doses at $20^{\circ} \mathrm{C}$

\begin{tabular}{lllll}
\hline Doses (IJs/larva) & \multicolumn{4}{l}{ Days after inoculation } \\
\cline { 2 - 5 } & 1 & 2 & 3 & 4 \\
\hline 10 & $0 \mathrm{a}^{\mathrm{x}}$ & $70 \mathrm{a}$ & $100 \mathrm{a}$ & $100 \mathrm{a}$ \\
20 & $0 \mathrm{a}$ & $70 \mathrm{a}$ & $100 \mathrm{a}$ & $100 \mathrm{a}$ \\
40 & $0 \mathrm{a}$ & $80 \mathrm{ab}$ & $100 \mathrm{a}$ & $100 \mathrm{a}$ \\
80 & $0 \mathrm{a}$ & $100 \mathrm{~b}$ & $100 \mathrm{a}$ & $100 \mathrm{a}$ \\
120 & $0 \mathrm{a}$ & $100 \mathrm{~b}$ & $100 \mathrm{a}$ & $100 \mathrm{a}$ \\
240 & $20 \mathrm{~b}$ & $100 \mathrm{~b}$ & $100 \mathrm{a}$ & $100 \mathrm{a}$ \\
\hline
\end{tabular}

$\mathrm{x}$ : Means $(n=20)$ in columns followed by the same letter do not significantly differ according to Tukey's multiple range test $(P<0.05)$ 
Table 5 Number of invader infective juveniles (IJs) per Galleria mellonella larva, percentage of penetration efficacy, emergence time and offspring (number of IJs) at $20^{\circ} \mathrm{C}$ and different doses of Steinernema feltiae LR

\begin{tabular}{lllll}
\hline Doses (IJs/larva) & Invader IJs & Penetration efficacy & Emergence time (days) & Offspring \\
\hline 10 & $2.4 \pm 1.7 \mathrm{a}^{\mathrm{x}}$ & $24 \pm 16.7 \mathrm{a}$ & $13.5 \pm 5.7 \mathrm{a}$ & $64,919.3 \pm 41,294.8 \mathrm{a}$ \\
20 & $6.6 \pm 1.8 \mathrm{~b}$ & $33 \pm 9.1 \mathrm{a}$ & $12 \pm 1.7 \mathrm{a}$ & $79,130.2 \pm 16,801.7 \mathrm{ab}$ \\
40 & $10 \pm 5.2 \mathrm{bc}$ & $25 \pm 13.3 \mathrm{a}$ & $11.2 \pm 0.5 \mathrm{a}$ & $95,787.8 \pm 18,570.1 \mathrm{abc}$ \\
80 & $20.8 \pm 3.9 \mathrm{~d}$ & $26.4 \pm 4.8 \mathrm{a}$ & $11.4 \pm 0.6 \mathrm{a}$ & $90,316.2 \pm 8542.4 \mathrm{abc}$ \\
120 & $40.8 \pm 17.3 \mathrm{de}$ & $34 \pm 14.3 \mathrm{a}$ & $11 \pm 0.7 \mathrm{a}$ & $106,152 \pm 13,569.3 \mathrm{c}$ \\
240 & $118.8 \pm 46.8 \mathrm{f}$ & $49.6 \pm 19.6 \mathrm{a}$ & $11.2 \pm 1.5 \mathrm{a}$ & $86,240 \pm 67,172 \mathrm{abc}$ \\
\hline
\end{tabular}

$\mathrm{x}$ : Means $(n=5)$ in columns followed by the same letter do not significantly differ according to Tukey's multiple range test $(P<0.05)$

Table 6 Assessment of mortality (\%) of Galleria mellonella larvae during 5 days after inoculation with Steinernema feltiae LR infective juveniles (IJS) in soil with different water contents

\begin{tabular}{llllll}
\hline Water content & \multicolumn{5}{l}{ Days after inoculation } \\
\cline { 2 - 6 } & 1 & 2 & 3 & 4 & 5 \\
\hline Permanent wilting point & $0 \mathrm{a}^{\mathrm{x}}$ & $73 \mathrm{a}$ & $93 \mathrm{a}$ & $98 \mathrm{a}$ & $100 \mathrm{a}$ \\
Field capacity & $2.5 \mathrm{a}$ & $93 \mathrm{~b}$ & $100 \mathrm{~b}$ & $100 \mathrm{a}$ & $100 \mathrm{a}$ \\
Saturation & $2.5 \mathrm{a}$ & $100 \mathrm{~b}$ & $100 \mathrm{~b}$ & $100 \mathrm{a}$ & $100 \mathrm{a}$ \\
\hline
\end{tabular}

$\mathrm{x}$ : Means $(n=20)$ in columns followed by the same letter do not differ according to Tukey's multiple range test $(P<0.05)$

be adapted to cold, capable of infecting hosts in temperatures between 8 and $28^{\circ} \mathrm{C}$ and able to produce offspring between 8 and $25^{\circ} \mathrm{C}$ [44-47]. Based on climatic conditions from the site of origin (mean temperature of $8{ }^{\circ} \mathrm{C}$ and $17.7^{\circ} \mathrm{C}$ in winter and summer, respectively), S. feltiae LR could be an isolate more adapted to cold conditions. However, below $10{ }^{\circ} \mathrm{C}$, the IJs were not able to infect G. mellonella, and $15-25^{\circ} \mathrm{C}$ was the optimum temperature range for infection and reproduction. This finding could indicate that the isolate's parasitic activities under natural conditions are higher in spring-summer. The optimal temperature ranges vary with the species and/or the isolate. Studies performed by Umana [48] with seven isolates of $S$. feltiae obtained from Chile [9] showed that at $20^{\circ} \mathrm{C}, \mathrm{G}$. mellonella death occurred at 48-72 $\mathrm{h}$, and the output of new larvae started within 13-14 days. At the same temperature, the isolate LR achieved highest larval mortality, and the number of days for IJ emergence was 3-4 days shorter.
Sáenz [49] considered that the mortality of S. feltiae is not dependent on the number of IJs penetrating the host, but Fan et al. [50] estimated that mortality increases with the amount of inoculum. According to our results, the number of nematodes able to enter the host increased with the number of IJs inoculated, but the efficacy of penetration was similar; this observation was also reported by Fan et al. [50] with S. feltiae, who obtained $100 \%$ mortality with an initial population ranging from 53 to 114 IJs per G. mellonella larva, and the penetration capacity was variable; about $20-50 \%$ of applied IJs penetrated the host. According to Lewis et al. [7], there is a minimum number required to overcome the insect's defenses and a maximum due to a high competence between them. In our study, with 240 IJs per larva, the reproductive rate was minimum. It is also interesting that according to $\mathrm{CL}_{90}$, with 40.4 IJs/larva, there was no increase in mortality from the 2nd DAI, showing that over an inoculum dose threshold, mortality does not increase. Koppenhöfer and Kaya [51] observed that an increase in dose of S. glaseri in soil affected the penetration and reproduction in $G$. mellonella larvae. They observed that the highest number of new IJs occurred between 20.7 and 58 IJs per larva and that no reproduction was observed with 184.4 specimens or more.

Moisture is another important soil factor for survival and infectivity of NEPs, since they need a water film around them for movement [52-54]. The water content in soil may affect movement, penetration and other factors depending on the nematode species and

Table 7 Incidence of soil water content in number of invader infective juveniles (IJS) per insect larva, percentage of penetration, emergence days and offspring (number of IJS) of Steinernema feltiae LR

\begin{tabular}{lllll}
\hline Water content & Invader IJs & Penetration efficacy & Time of emergence & Offspring \\
\hline Permanent wilting point & $24.9 \pm 11.5 \mathrm{a}^{\mathrm{x}}$ & $20.8 \pm 11.5 \mathrm{a}$ & $10.1 \pm 1.6 \mathrm{a}$ & $75,180.1 \pm 37,210.5 \mathrm{a}$ \\
Field capacity & $36.8 \pm 21.4 \mathrm{a}$ & $30.8 \pm 21.4 \mathrm{a}$ & $10.5 \pm 0.7 \mathrm{a}$ & $81,518.3 \pm 24,150.1 \mathrm{a}$ \\
Saturation & $38.4 \pm 18.2 \mathrm{a}$ & $38.4 \pm 18.2 \mathrm{a}$ & $10.1 \pm 0.2 \mathrm{a}$ & $70,975.5 \pm 23,629.5 \mathrm{a}$
\end{tabular}

$\mathrm{x}$ : Means $(n=20)$ in columns followed by the same letter do not differ according to Tukey's multiple range test $(P<0.05)$ 
their physiological adaptations. The optimal ranges are variable across different species $[53,55]$. Infectivity and reproduction of $S$. feltiae LR were optimal when water content was near field capacity, similar to observations by Koppenhöfer and Fuzy [53] working with S. scarabei in sandy loam and loamy soils. Susurluk et al. [56] reported that the ideal water content for S. feltiae host penetration was $10 \%$, with drastic decreases when water content increased to $20 \%$. Gungor et al. [55] found similar results with Steinernema anatoliense, reporting an optimum at $10 \%$ of water content. In our study, the amount of water in the soil affected only the time needed to reach $100 \%$ mortality, being necessary one more day in the driest substrate, but efficacy and offspring were the same for the three water contents evaluated.

According to the results obtained, the species $S$. feltiae LR has ecological requirements that would allow it to be used in various areas of the country, where the conditions required for optimal development occur.

\section{Conclusions}

Due to their potential as biological control agents, the correct identification of EPNs and their symbiont bacteria, as well as the study of their ecological characteristics, is key for optimal management in pest control. Data have shown that S. feltiae LR shows certain variation in morphometric characteristic compared with other isolates from different geographic origins; molecular analysis also evidenced intra-specific variability. The LR isolate was shown to be efficient in water-containing soil, with optimal temperatures ranging from 15 to $25{ }^{\circ} \mathrm{C}$ for host infestation and production of an abundant offspring; these characteristics would allow its potential use as a control agent in a wide geographical area of the country.

\section{Abbreviations \\ IJs: Infective juveniles; ITS: Internal transcribed spacer; EPNs: Entomopatho- genic nematodes; LR: Lican Ray; NCBI: National Center for Biotechnology Information; LSU: Large ribosomal subunit; ML: Maximum likelihood; DAI: Days after inoculation; $\mathrm{LC}_{50}$ : Lethal concentration 50; $\mathrm{LC}_{90}$ : Lethal concentration 90.}

\section{Acknowledgements}

The authors thank Dr. Patricia Stock from the University of Arizona for her support to the first author, P. Flores, during the stay in her laboratory and to Universidad de Chile for the financial support to this study.

\section{Authors' contributions}

PF participated in data analysis and performed morphological and molecular descriptions. AA assisted with the in vitro assays. GL and PL performed the statistical analysis and contributed to writing the manuscript, respectively. SP participated in the data molecular analysis. EA designed the study and participated in the manuscript writing. All authors read and approved the final manuscript.

\section{Funding}

The study was financially supported by University of Chile.

\section{Availability of data and materials}

Our sequences were deposited in the GenBank database under the accession numbers MK504438 (ITS rRNA), MK504439 (ITS rRNA), MK509752 (28S rRNA), MK509780 (28S rRNA) and MK504451 (16S rRNA). Data supporting the conclusions of this article are included within the article. The datasets used and/ or analyzed during the current study are available from the corresponding author upon reasonable request.

\section{Ethics approval and consent to participate}

Not applicable.

\section{Consent for publication}

Not applicable.

\section{Competing interests}

The authors declare that they have no competing interests.

\section{Author details}

${ }^{1}$ Departamento de Sanidad Vegetal, Facultad de Ciencias Agronómicas, Universidad de Chile, P.O. Box 1004, Santiago, Chile. ${ }^{2}$ Instituto de Diversidad y Ecología Animal (CONICET-UNC) y Centro de Zoología Aplicada, Facultad de Ciencias Exactas, Físicas y Naturales, Universidad Nacional de Córdoba, X5000AVP Córdoba, Argentina.

Received: 5 September 2020 Accepted: 13 December 2020 Published online: 13 January 2021

\section{References}

1. Hunt DJ, Nguyen KB. Advances in taxonomy and phylogeny of entomopathogenic nematodes of the Steinernematidae and Heterorhabditidae. Nematology. Leiden-Boston: Brill; 2016. p. 454.

2. Askary TH. Nematodes as Biocontrol Agents. Sociology, Organic Farming, Climate Change and Soil Science. Dordrecht: Springer; 2010. p. 347-78.

3. Puža V, Mráček Z, Nermut J. Novelties in pest control by entomopathogenic and Mollusc-parasitic nematodes. In: Hill H, editor. Integrated Pest Management (IPM): Environmentally Sound Pest Management. London: InTech; 2016. p. 71-102.

4. Hinchliffe SJ. Insecticidal toxins from the Photorhabdus and Xenorhabdus bacteria. Open Toxinol J. 2010;3:101-18.

5. Kupferschmied P, Maurhofer M, Keel C. Promise for plant pest control: root-associated pseudomonads with insecticidal activities. Front Plant Sci. 2013;4:287.

6. Campos-Herrera R, Gutiérrez C. Steinernema feltiae intraspecific variability: infection dynamics and sex-ratio. J Nematol. 2014;46:35-43.

7. Lewis EE, Campbell J, Griffin C, Kaya H, Peters A. Behavioral ecology of entomopathogenic nematodes. Biol Control. 2006;38:66-79.

8. Campos-Herrera R, Barbercheck M, Hoy CW, Stock SP. Entomopathogenic nematodes as a model system for advancing the frontiers of ecology. J Nematol. 2012;44:162-76.

9. Edgington S, Buddie AG, Moore D, France A, Merino L, Tymo LM, et al. Diversity and distribution of entomopathogenic nematodes in Chile. Nematol. 2010;12:915-28.

10. Edgington S, Buddie AG, Moore D, France A, Merino L, Hunt DJ. Heterorhabditis atacamensis n. sp. (Nematoda: Heterorhabditidae), a new entomopathogenic nematode from the Atacama Desert, Chile. J Helminthol. 2011;85:381-94.

11. Edgington S, Buddie AG, Tymo LM, France A, Merino L, Hunt DJ. Steinernema unicornum sp. n. (Panagrolaimomorpha: Steinernematidae), a new entomopathogenic nematode from Tierra del Fuego, Chile. J Nematode Morphol Syst. 2009;12:113-31.

12. Edgington S, Buddie AG, Tymo L, Hunt DJ, Nguyen KB, France Al, et al. Steinernema australe n. sp. (Panagrolaimomorpha: Steinernematidae), a new entomopathogenic nematode from Isla Magdalena, Chile. Nematol. 2009;11:699-717.

13. Bedding RA, Akhurst RJ. A simple technique for the detection of insect paristic rhabditid nematodes in soil. Nematologica. 1975;21:109-10. 
14. Kaya HK, Patricia Stock S. Techniques in insect nematology. Manual of techniques in insect pathology. Amsterdam: Elsevier; 1997. p. 281-324.

15. Akhurst RJ. Morphological and functional dimorphism in Xenorhabdus spp., bacteria symbiotically associated with the insect pathogenic nematodes Neoaplectana and Heterorhabditis. Microbiology. 1980;121:303-9.

16. Boemare N, Thaler J-O, Lanois A. Simple bacteriological tests for phenotypic characterization of Xenorhabdus and Photorhabdus phase variants. Symbiosis. 1997;22:167-75.

17. Singh S, Eric M, Floyd I, Leonard HD. Characterization of Photorhabdus luminescens growth for the rearing of the beneficial nematode Heterorhabditis bacteriophora. Indian J Microbiol. 2012;52:325-31.

18. Seinhorst JW. A rapid method for the transfer of nematodes from fixative to anhydrous glycerin. Nematologica. 1959;4:67-9.

19. Hominick WM, Briscoe BR, del Pino FG, Heng J, Hunt DJ, Kozodoy E, et al. Biosystematics of entomopathogenic nematodes: current status, protocols and definitions. J Helminthol. 1997;71:271-98.

20. Koppenhöfer A, Stock SP. Steinernema scarabaei n. sp. (Rhabditida: Steinernematidae), a natural pathogen of scarab beetle larvae (Coleoptera: Scarabaeidae) from New Jersey, USA. Nematol. 2003;5:191-204.

21. Williams BD, Schrank B, Huynh C, Shownkeen R, Waterston RH. A genetic mapping system in Caenorhabditis elegans based on polymorphic sequence-tagged sites. Genetics. 1992;131:609-24.

22. Nadler SA, Hudspeth DSS. Ribosomal DNA and phylogeny of the Ascaridoidea (Nemata: Secernentea): Implications for morphological evolution and classification. Mol Phylogenet Evol. 1998;10:221-36.

23. Thomas WK, Vida JT, Frisse LM, Mundo M, Baldwin JG. DNA sequences from formalin-fixed nematodes: integrating molecular and morphological approaches to taxonomy. J Nematol. 1997;29:250-4.

24. Nadler SA, Hoberg EP, Hudspeth DS, Rickard LG. Relationships of Nematodirus species and Nematodirus battus isolates (Nematoda: Trichostrongyloidea) based on nuclear ribosomal DNA sequences. J Parasitol. 2000;86:588-601.

25. Stock SP, Campbell JF, Nadler SA. Phylogeny of Steinernema travassos, 1927 (Cephalobina: Steinernematidae) inferred from ribosomal DNA sequences and morphological characters. J Parasitol. 2001;87:877-89.

26. Lane DJ. 16S/23S rRNA sequencing. In: Stackebrandt E, Goodfellow M, editors. Nucleic acid techniques in bacterial systematics. 1st ed. New York: Wiley; 1991. p. 115-75.

27. Larkin MA, Blackshields G, Brown NP, Chenna R, McGettigan PA, McWilliam H, et al. Clustal W and Clustal X version 20. Bioinformatics. 2007;23:2947-8.

28. Hall TA. BioEdit: a user-friendly biological sequence alignment editor and analysis program for Windows 95/98/NT. Nucleic Acids Symp Ser. 1999;41:95-8.

29. Tamura K, Nei M, Kumar S. Prospects for inferring very large phylogenies by using the neighbor-joining method. Proc Natl Acad Sci. 2004;101:11030-5.

30. Tamura K, Stecher G, Peterson D, Filipski A, Kumar S. MEGA6: molecular evolutionary genetics analysis version 6.0. Mol Biol Evol. 2013;30:2725-9.

31. Ronquist F, Huelsenbeck JP. MrBayes 3: Bayesian phylogenetic inference under mixed models. Bioinformatics. 2003;19:1572-4.

32. Posada D. jModelTest: phylogenetic model averaging. Mol Biol Evol. 2008;25:1253-6.

33. Page RDM. Tree view: an application to display phylogenetic trees on personal computers. Bioinformatics. 1996;12:357-8.

34. Abbott W. A method of computing the effectiveness of an insecticide. J Econ Entomol. 1925;18:265-7.

35. Yoshida M. Intraspecific variation in RFLP patterns and morphological studies on Steinernema feltiae and S. kraussei (Rhabditida: Steinernematidae) from Hokkaido, Japan. Nematol. 2003;5:735-46.

36. Campos-Herrera R, Escuer M, Robertson L, Gutiérrez C. Morphological and ecological characterization of Steinernema feltiae (Rhabditida: Steinernematidae) Rioja strain isolated from Bibio hortulanus (Diptera: Bibionidae) in Spain. J Nematol. 2006;38:68-75.

37. Nguyen KB, Mracek Z, Webster JM. Morphological and molecular characterization of a new isolate of Steinernema feltiae (Filipjev, 1934) from Vancouver, Canada, with morphometrical comparison with the topotype population from Russia. Zootaxa. 2006;1132:51.

38. Addis T, Mulawarman M, Wayenberge L, Moens M, Viaene N, Ehlers RU. Identification and intraspecific variability of Steinernema feltiae strains from Cemoro Lawang village in Eastern Java, Indonesia. Russ J Nematol. 2011;19:21-9.

39. Akyazi F, Ansari MA, Ahmed BI, Crow WT, Mekete T. First record of entomopathogenic nematodes (Steinernematidae and Heterorhabditidae) from Nigerian soil and their morphometrical and ribosomal DNA sequence analysis. Nematol Mediterr. 2012;40:95-100.

40. Ertürk Ö, Ostaoğlu F, Akyazi F. Occurrence and Distribution of entomopathogenic nematodes (Steinernematidae and Heterorhabditidae) in Ordu Province, Turkey. Turk J Agric Nat Sci. 2014;1:469-80.

41. Nikdel M, Niknam G. Morphological and molecular characterization of a new isolate of entomopathogenic nematode, Steinernema feltiae (Filipjev) (Rhabditida: Steinernematidae) from the Arasbaran forests, Iran. J Asia-Pac Biodivers. 2015;8:144-51.

42. Pưža V, Chundelová D, Nermut' J, Žurovcová M, Mráček Z. Intra-individual variability of ITS regions in entomopathogenic nematodes (Steinernematidae: Nematoda): implications for their taxonomy. Biocontrol. 2015;60:547-54.

43. Zeng $F$, Xue $R$, Zhang $H$, Jiang $T$. A new gene from Xenorhabdus bovienii and its encoded protease inhibitor protein against Acyrthosiphon pisum Pest Manag Sci. 2012;68:1345-51.

44. Wright PJ. Cool temperature reproduction of steinernematid and heterorhabditid nematodes. J Invertebr Pathol. 1992;60:148-51.

45. Grewal PS, Selvan S, Gaugler R. Thermal adaptation of entomopathogenic nematodes: Niche breadth for infection, establishment, and reproduction. J Therm Biol. 1994;19:245-53.

46. Grewal BPS, Gaugler R, Wang YI. Enhanced cold tolerance of the entomopathogenic nematode Steinernema feltiae through genetic selection. Ann Appl Biol. 1996;129:335-41.

47. Hazir S, Stock SP, Kaya HK, Koppenhöfer AM, Keskin N. Developmental temperature effects on five geographic isolates of the entomopathogenic nematode Steinernema feltiae (Nematoda: Steinernematidae). J Invertebr Pathol. 2001;77:243-50.

48. Umana EK. Biological aspects of new Steinernema feltiae isolate from Chile. University of Reading; 2014.

49. Sáenz A. Eficacia de invasión de Tecia solanivora y Clavipalpus ursinus por el nematodo Steinernema feltiae. Manejo Integr Plagas y Agroecol. 2003;67:35-43.

50. Fan X, Maggiorani A, Gudiño S. Uso de nemátodos entomopatógenos como una alternativa en el control de polilla Tecia solanivora, importante plaga de la papa (Solanum tuberosum). Rev For Venez. 2000;44:115-8.

51. Koppenhöfer A, Kaya H. Density-dependent effects on Steinernema glaseri (Nematoda: Steinernematidae) within an insect host. J Parasitol. 1995;81:797-9.

52. Grant JA, Villani MG. Soil moisture effects on entomopathogenic nematodes. Environ Entomol. 2003;32:80-7.

53. Koppenhöfer AM, Fuzy EM. Soil moisture effects on infectivity and persistence of the entomopathogenic nematodes Steinernema scarabaei, S glaseri, Heterorhabditis zealandica, and H bacteriophora. Appl Soil Ecol. 2007;35:128-39.

54. Morton A. Los nematodos entomopatógenos (Rhabditida: Steinernematidae y Heterorhabditidae) para el control del gusano cabezudo, Capnodis tenebrionis (Coleoptera: Buprestidae). Universidad Autonoma de Barcelona; 2009.

55. Gungor DS, Keskin N, Hazir S. Ecological characterization of Steinernema anatoliense (Rhabditida: Steinernematidae). J Invertebr Pathol. 2006;92:39-44.

56. Susurluk A, Wyss U, Ehlers R-U, Strauch O, Stackebrandt E, Dix I. Identification and ecological characterisation of three entomopathogenic nematode-bacterium complexes from Turkey. Nematol. 2001;3:833-41.

\section{Publisher's Note}

Springer Nature remains neutral with regard to jurisdictional claims in published maps and institutional affiliations. 